症国

\title{
両側乳癌手術症例の検討
}

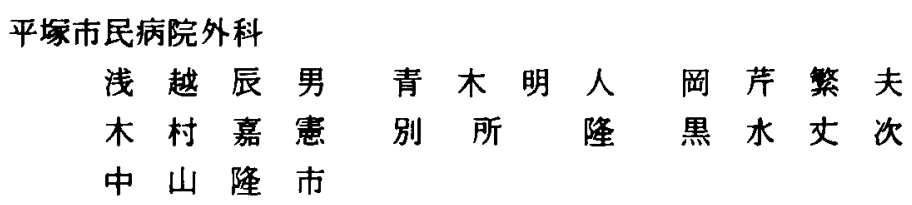

\section{SURGICAL TREATMENT FOR BILATERAL BREAST CANCER}

Tatsuo ASAGOE, Akahito AOKI, Shigeo OKAZERI, Yoshinori KIMURA, Takashi BESSYO, Joji KUROMIZU and Ryuichi NAKAYAMA

Department of Surgery, Hiratsuka City Hospital

最近10年 8 力月間に取り扱った原発乳癌症例179例のらち，原発性両側乳癌は 2 例 (1.1\%), 転移性両側乳癌は 8 例 $(4.5 \%)$ であった。このうち両側共乳房切断術を施行 したのは, 原発性 2 例, 転移性 5 例であった。

原発性両側乳癌症例の 1 例は, 第 1 癌 T1NO, 第 2 癌 T1NO, 潜在期間 3 力月で両側 共病理学的に非浸润癌, す5 1 例は第 1 癌 T2NO, 第 2 癌 TONO, 潜在期間170力月で あった。転移性両側乳癌手術例 5 例の潜在期間は 0 から 102 力月, 平均 40.2 力, 転㷌は 第 2 癌術後最短 9 月死亡, 最長 29 月健在例であった。

手術術式は，原発性癌の 1 例は両側共非浸潤癌のため非定型的乳房切断術を施行し， も5 1 例は両側共定型的乳房切断㭪を施行した。一方, 転移性の第 2 癌に対しては, 単 乳切を 1 例，非定型乳切を 4 例施行した，われわれは，転移性両側乳癌に対しては，他 の臓器に転移, 再発のないことを確認したのち, 積極的に乳房切断術を施行して腫場の 減量を図るようにしているか，転移性第 2 癌術後29力月の健在例もあり，外科治療は延 命効果が高いと考えている.

はじめに

乳癌症例の增加がみられる現今でも，両側乳癌は比 㬵的まれな疾患である。1971年 1 月より10年 8 カ月間 K, 平塚市民病完外科で取り扱った原発乳癌症例は 179 例で，このらち原発性両倒乳癌は 2 例 $(1.1 \%)$, 転移 性同側乳癌は 8 例 (4.5\%)であった。今回は，両側乳 癌症例10例のうち両側共乳房切断術を施行した 7 例の 娭討を中心に，㭪後再発形式の観点より考察を加えて 報告する。

\section{1. 两側釈诸手術症例}

最近10年 8 カ月間に当院外科で取り扱った両側乳癌 症例は10例あるが，この5ち両側共乳房切断洏を施行 したのは，原発性 2 例，転移性 5 例の合計 7 例であっ た(表 1). 原発性両側乳癌の判定基準は，第 7 回乳癌
研究会1のものによった，原発性両側乳癌症例は 2 例 あり, 症例 1 . は 3 力月の間隔で両側非定型的乳房切 断術を施行したが，両側共非浸潤性乳頭腺管癌で no であった。症例 2 ．は，左側の定型的乳房切断術後 170 カ月にて血性乳頭分泌を主訴とした TO 症例で， microdochectomyにより一部に漫潤像をみる乳頭腺管 癌を認めた。この 2 例共, 原発性両側乳癌の範畤に入 ると考えられる。

転移性両側乳癌症例で手術を施行した症例は 5 例あ $\eta$ ，第 1 癌手術時の年龄は 34 から55歳，平均 44.0 歳， 臨床病期は Stage I $: 1$ 例, II $: 2$ 例, III：1 例, IV : 1 例で, 第 1 癌より第 2 癌までの潜在期間は 0 から102 カ月, 平均 40.2 カ月であった。

第 2 癌に対する手術術式は，原発性の場合，非定型 
表 1 両側販病手術症例

\begin{tabular}{|c|c|c|c|c|c|c|c|c|c|}
\hline \multirow[b]{2}{*}{ No. } & \multirow{2}{*}{$\begin{array}{l}\text { 年 } \\
\text { 㓥命 }\end{array}$} & 笌 & \multicolumn{2}{|r|}{ 癌 } & \multirow{2}{*}{$\begin{array}{l}\text { 篔 在 } \\
\text { 期 间 }\end{array}$} & \multicolumn{2}{|l|}{ 第 } & 㾂 & \multirow[b]{2}{*}{ 枟禺 } \\
\hline & & $\begin{array}{l}\text { 部 位 } \\
\text { 病 期 }\end{array}$ & $\begin{array}{c}\text { 術 式 } \\
\text { 蒲助㾜法 }\end{array}$ & 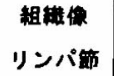 & & $\begin{array}{l}\text { 部 位 } \\
\text { 病 期 }\end{array}$ & $\begin{array}{c}\text { 街 式 } \\
\text { 補助㾜法 }\end{array}$ & $\begin{array}{l}\text { 粗辁像 } \\
\text { リンパ節 }\end{array}$ & \\
\hline 1 & 42 & $\begin{array}{ll}\text { 古中央 } & \\
\mathrm{T}_{\text {IN }} \mathrm{N}_{0} & \text { (1) }\end{array}$ & 非定型 & $\begin{array}{l}\text { I a ) - D } \\
0 / 24\end{array}$ & 3 月 & $\begin{array}{|ll|}\text { 左外下 } & \\
T_{1} N_{0} & \text { (I) } \\
\end{array}$ & 非定型 & $\begin{array}{l}1 \text { a )-1) } \\
0 / 18 \\
\end{array}$ & 18月件 \\
\hline 2 & 55 & $\begin{array}{ll}\text { 左内下 } & \\
\mathrm{T}_{2} \mathrm{~N}_{0} & \text { (II) }\end{array}$ & $\begin{array}{ll}\text { 定 型 } \\
\text { 照 射 }\end{array}$ & $\begin{array}{l}\text { (I a ) -2) } \\
0 / 10\end{array}$ & 170月 & $\begin{array}{l}\text { 右血性分椡 } \\
\text { (内下) } \mathrm{T} \text { oNo }\end{array}$ & $\begin{array}{l}\text { 定 型 } \\
5 F u\end{array}$ & $\begin{array}{l}\text { (I a ) }-1 \text { ) } \\
0 / 21\end{array}$ & 11月展 \\
\hline 3 & 51 & $\begin{array}{l}\text { 左中央 } \\
\mathrm{T}_{4} \mathrm{~N}_{2 \mathrm{M}} \mathrm{MUN}\end{array}$ & 定 型 & $\begin{array}{l}\text { (1 a ) }-3 \text { ) } \\
19 / 19\end{array}$ & 0 & $\begin{array}{ll}\text { 右内上 } & \\
\mathrm{T}_{3} \mathrm{~N}_{2} & \text { (而) }\end{array}$ & $\begin{array}{l}\text { 非定型・期 } \\
\text { ADR·5Fu }\end{array}$ & $\begin{array}{l}\text { (I a ) }-3 \text { ) } \\
18 / 20\end{array}$ & 18 月㫿 \\
\hline 4 & 55 & $\begin{array}{|ll|}\text { 古外上 } & \\
\mathrm{T}_{3} \mathrm{~N}_{1} & \text { (III) }\end{array}$ & $\begin{array}{l}\text { 摭 大 } \\
5 F_{u}\end{array}$ & $\begin{array}{l}\text { (1 a ) }-2) \\
13 / 18\end{array}$ & 18月 & $\begin{array}{|ll|}\text { 左中央 } & \\
\mathrm{T}_{3} \mathrm{~N}_{2} & \text { (而) } \\
\end{array}$ & $\begin{array}{l}\text { 非定型·率 } \\
\text { ADR·5Fu }\end{array}$ & $\begin{array}{l}\text { I a ) }-2 \text { ) } \\
14 / 17\end{array}$ & 22月甠 \\
\hline 5 & 38 & $\begin{array}{|ll|}\text { 五外上 } & \\
\mathrm{T}_{2} \mathrm{~N}_{0} & \text { (II) } \\
\end{array}$ & $\begin{array}{c}\text { 摭 } 大 \\
5 F u \cdot M M C\end{array}$ & $\begin{array}{l}\text { (1) a }-2) \\
0 / 3\end{array}$ & 102 月 & $\begin{array}{|ll|}\text { 左外上 } & \\
\mathrm{T}_{2} \mathrm{~N}_{0} & \text { (II) } \\
\end{array}$ & $\begin{array}{l}\text { 非定型 } \\
\text { CPA }\end{array}$ & \begin{tabular}{|l|} 
(1 a ) -2 ) \\
$11 / 16$
\end{tabular} & 29月健 \\
\hline 6 & 42 & \begin{tabular}{|ll} 
左外上 & \\
$\mathrm{T}_{1} \mathrm{~N}_{0}$ & (I) \\
\end{tabular} & $\begin{array}{l}\text { 定 型 } \\
5 \mathrm{Fu}\end{array}$ & $\begin{array}{l}\text { II a )-1) } \\
15 / 17\end{array}$ & 27月 & 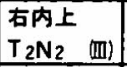 & $\begin{array}{l}\text { 非定型·明 } \\
\text { ADR-5Fu }\end{array}$ & $\begin{array}{l}(a)-1) \\
14 / 14\end{array}$ & $\begin{array}{l}\text { 9月亡 } \\
\text { (肺) }\end{array}$ \\
\hline 7 & 34 & \begin{tabular}{|ll} 
石外上 & \\
$\mathrm{T}_{2} \mathrm{~N}_{1}$ & (II)
\end{tabular} & $\begin{array}{l}\text { 拡 大 } \\
5 F u\end{array}$ & $\begin{array}{l}\text { Il a )-3) } \\
7 / 16\end{array}$ & 54 月 & $\begin{array}{|ll|}\text { 左中央 } & \\
\mathrm{T}_{3} \mathrm{~N}_{0} & \text { (II) }\end{array}$ & 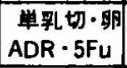 & $($ ( a ) -3 ) & $\begin{array}{l}\text { 21月亡 } \\
\text { (贯.肺) }\end{array}$ \\
\hline
\end{tabular}

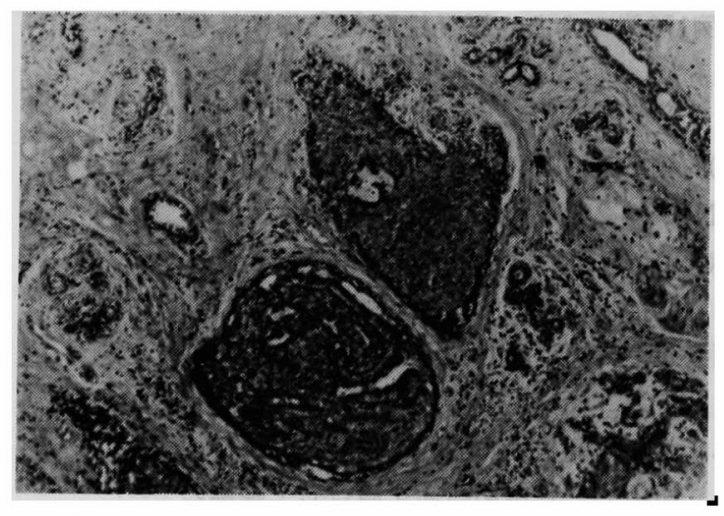

写共 1 症例 1 の第 1 瘦の病理組織像：非浸潤性乳頭 腺管癌の所見が認められる $(\times 40)$

1 例, 定型 1 例, 転移性の場合, 単乳切 1 例, 非定型 4 例で, 4 例に卵巣摘出術を施行した（表 1 ）.

\section{2. 茞瘦の占抛部位の比較}

両側乳癌10例の第 1 癌と第 2 癌における腫瘍の占拠 部位の比較を図 1 に示した。第 1 癌の部位としては， 外上の 5 例が最も多かった。 mirror image ${ }^{2)} に$ 相当す る対称部位の発生例は, 原発性 1 例, 転移珄 3 例の合 計 4 例 (40\%) であった。

3. 症例呈示

1) 症例 $1: 42$ 歳, 女性

右乳腺中央部の $9 \times 8 \mathrm{~mm}$ の小腫瘤を主訴として 来院し, 試切の結果, 非浸潤珄乳頭腺管癌であった。

(写真 1 ). 非定型的乳房切断術を施行し, 腋窩リンパ 節転移を認めなかった。第 1 癌術後 3 カ月にて左内下 部に $10 \times 10 \mathrm{~mm}$ の小腫瘤を認めたので, 試験的腫瘤摘

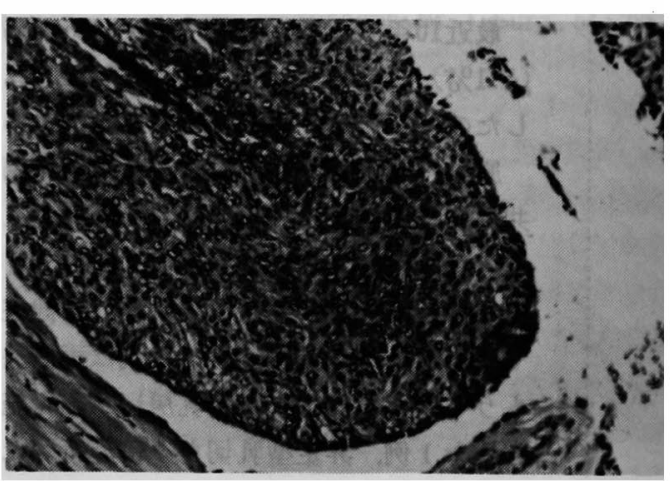

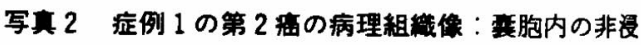
潤性乳腺管癌が認められる。（×100）

\begin{tabular}{|c|c|c|c|c|c|c|}
\hline 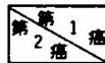 & 外 上 & 外 下 & 内 上 & 内 $下$ & 中 央 & it \\
\hline 外 上 & "IIII! I & & - & & $\bullet$ & 5 \\
\hline 外 下 & & & & & & 0 \\
\hline 内 上 & & & III & & & 1 \\
\hline 内 下 & & & & 9 & & 1 \\
\hline 中 央 & - & 0 & - & & & 3 \\
\hline to & 3 & 1 & 3 & 1 & 2 & 10 \\
\hline
\end{tabular}

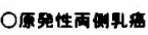

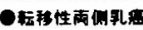

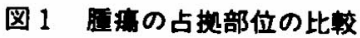

出術を施行した。病理組織学的には, 表胞内非浸洞珄 乳頭腺管癌であった（写真 2 ）。非定型乳切を施行し、 18 月後の現在健在である.この症例は， 3 カ月の間 


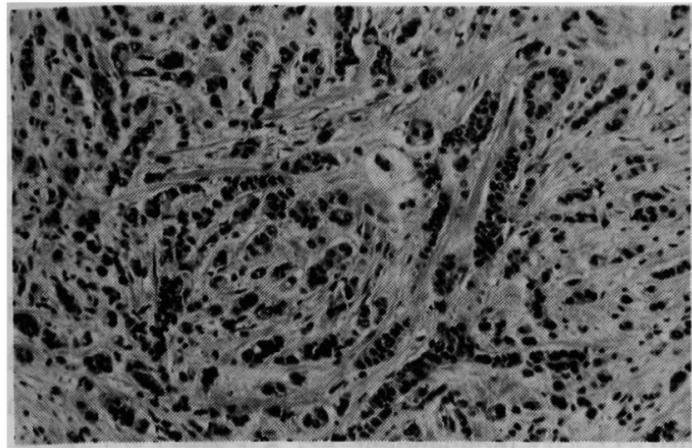

写真 3 症例の両側蔼の病理組維像：脈管浸潤がみら れ，辺縁への浸潤㑯向の強い硬澏の所見が認められ る. $(\times 100)$

隔で手術を受け，両側共非浸潤癌なので，同時性原発 性両側乳癌と考えられる。

2）症例 $3: 51$ 歳，女性

左乳腺中央部を中心に直径 $10.5 \times 11.0 \mathrm{~cm}$ の尰瘤が あり，皮庯の発赤，浮腫を伴なっていた，同時に右内 上部に $6.0 \times 5.5 \mathrm{~cm}$ の腫瘤を触知し, 両側の腋窩共固 い融合したリンパ節が認められたので，左側乳腺を第 1 癌 $\left(\mathrm{T}_{4} \mathrm{~N}_{2} \mathrm{M}_{1}\right)$, 右側を第 2 癌 $\left(\mathrm{T}_{3} \mathrm{~N}_{2}\right)$ とする同時性 転移性両側乳癌と判定した。遠隔転移の無いことを確 認して後, 第 1 癌の左側に対しては定型的乳房切断術, 第 2 癌の右側に対しては非定型乳切を施行し, 腋窩リ ソパ節転移は左側19/19，右側18/20で，両側共組織像 は硬癌であった（写真 3 ）. 術後, 5-FU, MMC, Endoxan, Adriamycin の 4 剂併用静注療法之5-FU 剂経口投与を続け，18カ月後の現在健在である.

\section{4. 乳瘦術後再発症例29例の䨀成}

最近10年 8 カ月間に当院外科で取り扱った原発乳癌 手術例179例の5ち, 再発を来した症例は29例あり, そ の構成を表 2．に示す，年齡は32から67歳，平均 47.7 歳, 踄床病期は Stage II：55\%, III：34\%が多く, 手 術術式別では非定型：4\%，定型：38\%，捘大：58\% であった，腋曧リンパ節転移個数別ではno：28\%， $n_{1-3}$ ケ: $17 \%, n_{4}$ ケ $: 55 \%$ であり, 乳癌研究会規約分 類 ${ }^{3)}$ 組織型では, 浸潤性䯣様腺管癌が $59 \%$ と最も多 く，次いで乳頭腺管癌：24\%，硬癌：17\%であった。 （1) 尰場辺縁漫潤性，(2) 脈管漫潤，(3) 細胞異型度 の 3 因子を主たる判定因子とする組織学的腫诲悪性 度》は, Grade I： 6\%, II : 28\%, III：66\%であった。 手術より再発までの潜在期間は 0 から86力月，平均 29.2力月で, 初発部位は, 対側乳腺・腋窩・鎖上が 5

\section{表 2 釈癌術啳再発29例の權成}

\begin{tabular}{|c|c|}
\hline 平均年龄 & 47.7触（32-67能） \\
\hline 監床病期 & I $: 4 \%$, II $: 55 \%$, III $: 34 \%$ \\
\hline 手術術式 & 非定型：4\%、定型：38\%、拡 \\
\hline 蓜リンパ第転䅣 & $n_{0}: 28 \%, n_{1-3}: 17 \%$, \\
\hline 組 端型 & $\mathrm{II}_{\mathrm{a}-1)}: 24 \% 、 \mathrm{II}_{\mathrm{a}-2)}: 59 \%$ 、 \\
\hline 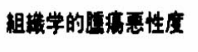 & I : $6 \%$, II : $28 \%$, III : 66 \\
\hline リニアック照射 & 照射：45\%、韭照射：55\% \\
\hline 平均潜在期间 & 29.2 月 $(0-86$ 月 $)$ \\
\hline 初発再発部位 & 局所：28\%、対側·銷上：17\% \\
\hline & $\begin{array}{l}\text { : }: 31 \% 、 \text { 肺 ・胸膜：14\% } \\
\text { 肝 }: 10 \%\end{array}$ \\
\hline
\end{tabular}

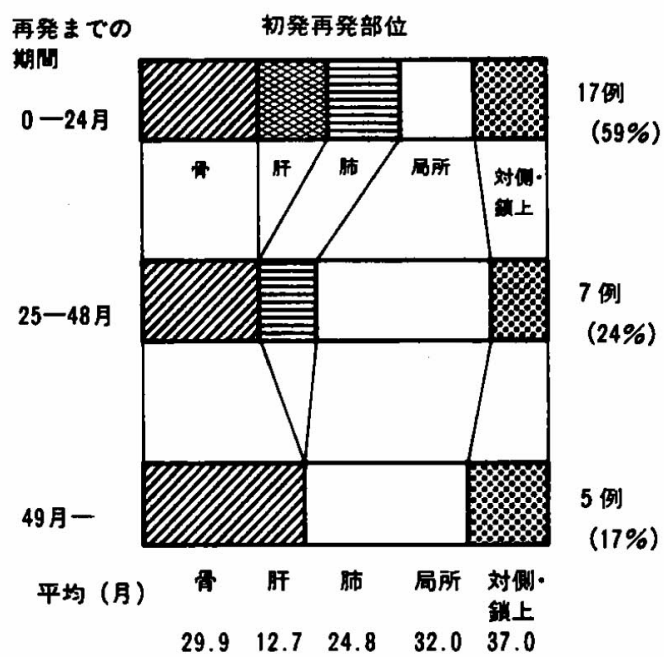

図 2 初発再発部位と術後再発までの期間

例 $(17 \%)$ あり，他に骨：31\%，局所：28\%，肺・胸 膜：14\%，肝：10\%であった（表 2 ）.

5. 初発再発部位上術後再発までの期間

再発29例の5ち17例（59\%）が術後24力月以内に再 発を来していた。初発再発部位と術後再発までの期間 の関係をみると，訮は24カ月以内の早期のみ，肺は48 カ月以内の早・中期のみ, 骨, 局所, 対側・鎖上は早・ 中・晚期のとの時期にすみられた。平均潜在期間は, 肝：12.7カ月, 肺 : 24.8 力, 骨: 29.9力月, 局所 : 32.0 月の順で, 対側・鎖上が最す長く 37.0 月であっ た（図 2 ).

6. 初発再発形式別の比較

初発再発形式を骨, 訮, 肺の血行群16例, 局所, 対 側・鎖上のリンパ行性群13例に大別して比較した。そ 
衰 3 初発再発形式別の比較

\begin{tabular}{|c|c|c|c|c|c|}
\hline & \multirow[b]{2}{*}{ 而 } & \multicolumn{2}{|c|}{ 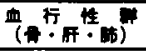 } & \multicolumn{2}{|c|}{ 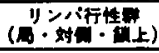 } \\
\hline \multirow{2}{*}{ 蛙 } & & 7 & $(44 \%)$ & 10 & $(77 \%)$ \\
\hline & \multirow{2}{*}{$\frac{\text { Stage I }}{\text { Sta }}$} & 9 & (56\%) & 3 & (23\%) \\
\hline \multirow{4}{*}{ 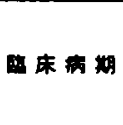 } & & \multicolumn{2}{|r|}{0} & 1 & $(8 \%)$ \\
\hline & II & 8 & (50\%) & 7 & $(54 \%)$ \\
\hline & III & 6 & $(38 \%)$ & 5 & (38\%) \\
\hline & v & 2 & (12\%) & \multicolumn{2}{|r|}{0} \\
\hline \multirow{2}{*}{ 证 切 } & 非椬 & 8 & $(50 \%)$ & 10 & (77\%) \\
\hline & 芷行 & 8 & $(50 \%)$ & 3 & (23\%) \\
\hline \multirow{3}{*}{ 手副瀮式 } & 韭定 跑 & 1 & $(6 \%)$ & \multicolumn{2}{|r|}{0} \\
\hline & 型 & 6 & $(38 \%)$ & 5 & $(38 \%)$ \\
\hline & 地 $大$ & 9 & $(56 \%)$ & \multicolumn{2}{|r|}{$(62 \%)$} \\
\hline \multirow{3}{*}{ 組 型 } & II $a-1)$ & 4 & $(25 \%)$ & 3 & $(23 \%)$ \\
\hline & 2) & 10 & $(63 \%)$ & \multicolumn{2}{|r|}{$(34 \%)$} \\
\hline & 3) & 2 & $(12 \%)$ & \multicolumn{2}{|r|}{$(23 \%)$} \\
\hline \multirow{3}{*}{ 粗億学的 } & & 1 & $(6 \%)$ & \multicolumn{2}{|r|}{$(8 \%)$} \\
\hline & II & 3 & $(19 \%)$ & \multicolumn{2}{|r|}{$(38 \%)$} \\
\hline & III & 12 & $(75 \%)$ & 7 & $(54 \%)$ \\
\hline & $n_{0}$ & 4 & $(25 \%)$ & 4 & $(31 \%)$ \\
\hline 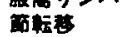 & $n_{1-3}$, & 3 & $(19 \%)$ & 2 & (15\%) \\
\hline & $n_{1} \cdot-$ & 9 & $(56 \%)$ & 7 & $(54 \%)$ \\
\hline リ & & 9 & $(56 \%)$ & 4 & $(31 \%)$ \\
\hline 雷射 & 非 盈 & 7 & $(44 \%)$ & 9 & $(69 \%)$ \\
\hline
\end{tabular}

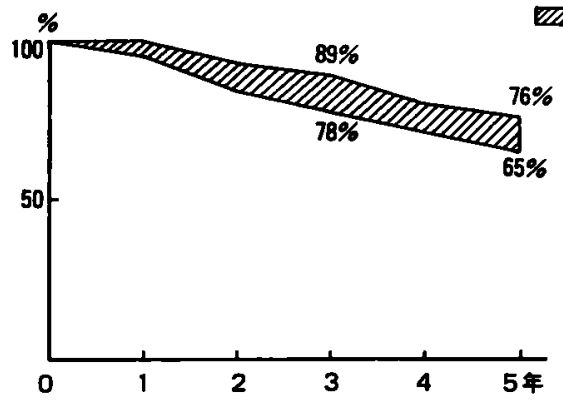

图3乳㾇根治術後の生存曲繶

の結果，1）リンバ行性群に年齢の若い閉経前症例， 進行した試切非施行例が多かった，2）両群とも髄様 腺管癌例，grade IIIの症例，腋窩リンパ節転移個数 4 個以上群の頻度が高いが，血行性群によりその傾向が 強い，3）術後リニアック照射は，血行性群の $56 \%$, リンバ行性群の $31 \%$ に施行していた（表 3).

\section{7. 乳语根治手術後の生存曲線}

乳癌根治手術後 5 年以上経過55例の 5 年生存曲線を 图 3 に示す。全体の 5 年生存率は $42 / 55(76 \%) ， 5$ 年 健在生存率は36/55 (65\%)，5年再発生存率は $6 /$ 55 (11\%) であった。

\section{考察}

両側乳癌は1800年 Nisbet ${ }^{5}$ が初めて報告しており， 本邦においては第 7 回乳癌研究会1)，第76回日本外科 学会の主題として取り上げられている.両側乳癌には，

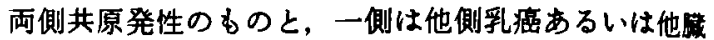
器よりの転移性のすのがありこの鑑別は容易の場合 が多いが，時には困難な場合もある。原発性か転称性 かの判定基準に関しては，1967年梶谷等 ${ }^{13}$ は原発性両 側乳癌は，1）異時性の場合，第 1 癌に根治㭪が施行 されていること，手術間隔か～ 6 力月以上のこと，第 2 癌手術時他に転移のないこと，2）同時性の場合，両 側共根治術の対象になること, 手術後早期に局所再発 をみないことと述へでおり，病理組織学的に一㑡が in situのむのは independent とすると報告している。一 方1964年 Robbins 等的は，転移性のるのは大部分りン ハ行性であるので，乳房実質周囲の脂肪組織内にしば しば認められ，正中線近くに存在するか，原発性癌は 乳腺組織内に発生し，外上部に特に多いと述へ，転移 性のものは多発性の傾向があり充実性增殖の形をとる か，原発性の場合は単発で星形，crablike な增殖を示 すと報告している。また1976年霞等》は，原発珄，転移 性の鑑別は第 2 癌の intraductal あるいは intralobu. lar spreadの有無でなされ，病理組織学的に spreadが あれば両側共原発生，なければ第 2 癌は第 1 癌あるい は他喊器癌よりの転移であると述べている，当院で最 近10年 8 力月間に取り扱った両側乳癌症例は10例あ ク，その内訳は原発性 2 例，転移性 8 例であったか， 当院の症例は原発性，転移性の鑑別に迷うことはな かった。

Urban"2) は乳癌の mirror image theory を提唱し， 対称側乳腺の生検を行ならべきであると主張したが, 1981年 Rosen 等8) は108例の lobular cancinoma in situの患者中57例 (51.8\%) に対称側の生検を施行し, 28例（25.9\%）に対側虞を発見したと報告している. 当院の両側乳癌症例10例の畽瘍占拠部位の比較では， 対称部位に第 2 癌が発生したのは原発性 1 例，転移性 3 例の計 4 例であった。

手術術式は，同時原発性癌例に対しては両侧共浸洞 癌のため非定型的乳房切断術を施行し，異時原発性例 に対しては両側共定型的乳房切断術を施行した。一方， 転移性の第 2 癌を発見した場合の治療方針としては， 他の缄器に轱移，再発のないことを確認したのち，費 極的に乳房切断術を施行し隀場の減量を図ることが延 命効果の上で大切と考えている，われわれはこの意四 で，単純乳房切断術を 1 例，非定型的乳房切断術を 4 例に施行したが，転移性第 2 癌術後最長29力月の健在 例もあり，患者の状態が許せばPatey の非定型的乳房 切断術を施行するようにしている。非定型的乳房切断 
行の原発乳癌に対する適応基準とその根拠に関しては

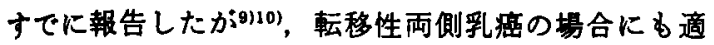
応が広げられると考えられている。

当院の乳癌術後再発症例29例の5ち初発再発部位が 対側乳腺，腋窝，鎖上であったのは 5 例 (17\%) で, 再発までの潜在期間は他の部位より長く，平均 37.0 カ 月であったが，早期，中期，晚期のどの時期にも出現 していたので，释過観察時に念頭に直きたい。 初発再発部位を血行性群とリンバ行性群の 2 形式に 大別しての比较では，対側乳腺転移を含むリンパ行性 群に年龄の若い進行した症例が多い㑯向が認められ た。 われわれは，若年者乳癌之高年者乳癌の臨床病理 学的比較検討をすでに報告したが'11，若年者の方が病 垱期間の長い進行症例が多く，また組織学的腫瘍悪性 度の末分化な症例る多かったので, それだけ術後再発 を来す可能性が高いと考えられた。

最後に転移性両側乳癌手術の補助療法は，局所の放 射線照射より, 今後の遠隔葴器転移に備えて化学㞠法 用の全身投与を第 1 としている(2)。化学療法剤は，5FU, MMC, Endoxan, Adriamycin の 4 剂併用投与を 中心にしている ${ }^{13)}$. 今後転移性両側乳癌症例に対し ては，積極的に乳房切断術を施行したのち，化学療法 鼡の全身投与により延命を図りたいと考克ている。

$$
\text { おわクに }
$$

最近10年 8 力月間に取り扱った両側乳癌症例10例の 5ち，乳房切断訹を施行した原発性 2 例，転移性 5 例 の検討を中心に報告した。

本諭文の要旨は，第19回日本癌治雴学会総会（於京都， 1981，10）において無表した。

$$
\text { 文献 }
$$

1) 第 7 回乳癌研究会編：主題 II. 両側乳癌, 癌の臨 床, $14: 682-686,1968$.

2) Urban, J.A.: Bilaterality of cancer of the breast. Biopsy of the opposite breast. Cancer, $20: 1867-1870,1867$.

3）乳痘研究会編：乳癌取扱い規約. 金原出版, 1976.

4) Fisher, E.R., Gregorio, R.M. and Fisher, B. : The pathology of invasive breast cancer. A syllabus derived from findings of the National Surgical Adjuvant Breast Project (Protocol N. 4). Cancer, $36: 1-85,1975$.

5) Haagensen, C.D. : Diseases of the breast, 2nd ed. W.B. Saunders Company, Philadelphia, 1971.

6) Robbins, G.F. and Berg, J.W.: Bilateral breast cancers. A prospective clinicopathological study. Cancer, 17 : 1501-1527, 1964.

7）震富士雄，姆 雅晴，深見敦夫他：両側乳癌，癌の 臨床，22：1941-1949，1976.

8) Rosen, P.P., Braun, D.W. and Kinn, D.W., et al. Lobular carcinoma in situ of the breast. Preliminary results of treatment by ipsilateral mastectomy and contralateral breast biopsy. Cancer, $47:$ 813-819, 1981.

9）浅越辰男, 青木明人，中山隆市他：TOおょび非浸 洞性乳癌の臨床病理学的検討，癌の臨床，27： 627-632, 1981.

10）浅越辰男, 青木明人, 中山隆市他：当浣における乳 癌治療の現況，外科診療，23：209-213，1981.

11）浅越辰男, 青木明人, 中山隆市他：若年者乳癌之高 年者乳癌の臨床病理学的比校馀討, 臨外会誌, 42 ： 294-299, 1981.

12) Carbone, P.P.: Chemotherapy of disseminated breast cancer. Current status and prospects. Cancer, 39 : 2916-2921, 1977.

13）浅越辰男, 青木明人，中山隆市他：乳癌術後再発症 例の臨床病理学的検討, 外科, 43:801-805, 1981. 